\title{
MODELS AND SOFTWARE SOLUTIONS FOR THE PROBLEM OF DIAGNOSING THE FINANCIAL STATE OF IT-ENTERPRISE
}

Today, the economy of Ukraine is in a relatively unstable position; therefore, Ukrainian enterprises require effective management. But in order to effectively manage the enterprise, you need to know what state it is in. Solving the problem of diagnosing the financial state of an enterprise in the future will allow developing an apparatus of effective management decisions that will help maintain the enterprise at the proper level of functioning and ensure further development of both the enterprises and the economy as a whole. The relevance of research is manifested in the application of the results for operational and effective management. The problem is in the need to obtain a more accurate solution for the problem of diagnosing the financial state of the enterprise with the parameters that characterize the financial situation best of all. The main objective of the research was to solve the problem of diagnosing the financial state of an IT company, using a model that implements a certain approach in order to obtain a qualitative conclu sion about the state of a company. A method based on the use of a fuzzy logic apparatus, namely, production models with a Mamdani fuzzy inference algorithm is proposed for solving the problem. There are 10 input parameters were allocated to determine the financial state. The criteria according to which the state was assessed were quantitative and qualitative indicators of the company's activity over the selected period. The resulting mathematical model allows to take into consideration both quantitative and qualitative indicators. The results of the research give an understanding of what indicators and how affect the financial condition of the company, and can also be used in the future, for example, to solve the forecasting problem. The implementation of research results can help speed up the diagnosis of the financial state of the enterprise and make a right management decision based on the results of diagnosis in time.

Keywords: diagnosing, financial state, financial indicator, fuzzy logic, production model, Mamdani algorithm, rule base.

\section{О. Є. ГОЛОСКОКОВ, Д. В. ТКАЧЕНКО МОДЕЛІ І ПРОГРАМНІ РІШЕННЯ ЗАДАЧІ ДІАГНОСТУВАННЯ ФІНАНСОВИХ СТАНІВ ІТ-ПІДПРИЕМСТВА}

На сьогоднішній день, економіка України знаходиться у відносно нестабільному положенні, тому підприємства України вимагають ефективного управління. Але для того щоб ефективно управляти підприємством, необхідно знати в якому стані воно знаходиться. Рішення задачі діагностування фінансового стану підприємства в подальшому дозволить розробляти апарат ефективних управлінських рішень, які допоможуть підтримувати підприємство на належному рівні функціонування і забезпечувати подальший розвиток, як самих підприємств, так і економіки в цілому. Актуальність досліджень проявляється в застосуванні отриманих результатів для оперативного і ефективного управління. Проблема полягає в необхідності отримання більш точного рішення задачі діагностування фінан сових станів підприємства, з урахуванням параметрів, що характеризують фінансовий стан найкраще. Основним завданням дослідження було рішення задачі діагностування фінансових станів IT-компанії, за допомогою моделі, що реалізує певний підхід з метою отримання якісного висновку про стан компанії. Для вирішення завдання пропонується метод, заснований на застосуванні апарату нечіткої логіки, а саме продукційних моделей з алгоритмом нечіткого висновку Мамдані. Для визначення фінансового стану були виділені 10 вхідних параметрів. Критеріями, за якими оцінювався стан, були кількісні та якісні показники діяльності компанії за обраний період. Отримана математична модель дозволяє враховувати як кількісні, так і якісні показники. Отримані результати дослідження дають розуміння про те, які показники і як саме впливають на фінансовий стан компанії, а також в подальшому можуть використовуватися, наприклад, для вирішення задачі прогнозування. Впровадження результатів дослідження може допомогти прискорити проведення діагностування фінансового стану на підприємстві, а також вчасно прийняти те чи інше управлінське рішення, засноване на результатах діагностування. правил.

Ключові слова: діагностування, фінансовий стан, фінансовий показник, нечітка логіка, продукційна модель, алгоритм Мамдані, база

\section{А. Е. ГОЛОСКОКОВ, Д. В. ТКАЧЕНКО \\ МОДЕЛИ И ПРОГРАММНЫЕ РЕШЕНИЯ ЗАДАЧИ ДИАГНОСТИРОВАНИЯ ФИНАНСОВЫХ СОСТОЯНИЙ ІТ-ПРЕДПРИЯТИЯ}

На сегодняшний день, экономика Украины находится в относительно нестабильном положении, поэтому предприятия Украины требуют эффективного управления. Но для того чтобы эффективно управлять предприятием, необходимо знать в каком состоянии оно находится. Решение задачи диагностирования финансового состояния предприятия в дальнейшем позволит разрабатывать аппарат эффективных управленческих решений, которые помогут поддерживать предприятие на должном уровне функционирования и обеспечивать дальнейшее развитие, как самих предприятий, так и экономики в целом. Актуальность исследований проявляется в применении полученных результатов для оперативного и эффективного управления. Проблема заключается в необходимости получения более точного решения задачи диагностирования финансовых состояний предприятия, с учетом параметров, характеризующих финансовое положение лучше всего. Основной задачей исследования являлось решение задачи диагностирования финансовых состояний IT-компании, с помощью модели, реализующей определенный подход с целью получения качественного заключения о состоянии компании. Для решения задачи предлагается метод, основанный на применении аппарата нечеткой логики, а именно продукционных моделей с алгоритмом нечеткого вывода Мамдани. Для определения финансового состояния были выделены 10 входных параметров. Критериями, по которым оценивалось состояние, были количественные и качественные показатели деятельности компании за выбранный период. Полученная математическая модель позволяет учитывать как количественные, так и качественные показатели. Полученные результаты исследования дают понимание о том, какие показатели и как именно влияют на финансовое состояние компании, а также в дальнейшем могут использоваться, например, для решения задачи прогнозирования. Внедрение результатов исследования может помочь ускорить проведение диагностирования финансового сост ояния на предприятии, а также вовремя принять то или иное управленческое решение, основанное на результатах диагностирования.

Ключевые слова: диагностирование, финансовое состояние, финансовый показатель, нечеткая логика, продукционная модель, алгоритм Мамдани, база правил.

Introduction. In the conditions that have emerged today, the Ukrainian economy is in a relatively unstable

situation; therefore, Ukrainian enterprises require effective management in order to prevent the bankruptcy of 
enterprises, which in turn can lead to a sharp decline of the economy. Among a number of tasks that are solving in the field of effective management, an important role takes the task of diagnosing the financial state of an enterprise, because it is impossible to manage effectively without knowing the condition of the control object.

Solving the problem of diagnosing the financial state of an enterprise in the future will allow developing an apparatus of effective management decisions that will help maintain the enterprise at the proper level of functioning and ensure further development of both the enterprises and the economy as a whole. In modern conditions of development of information technology, the automation of the diagnostic process can also significantly improve the efficiency of the enterprise. Some IT-company is considered as an enterprise.

The relevance of diagnosing the financial condition of an enterprise over time is obvious, because obtaining financial states is a necessary tool for strategic planning and management in the economic sector. Accurate determination of financial status provides an adequate understanding of the situation and the direction in which you need to act. The relevance of research is manifested in the application of the results for operational and effective management.

Timely and accurate determination of the financial state of the company is one of the main conditions for its successful development and functioning. Accurate determination of the financial condition in modern conditions is the reason for the need to have approaches that help determine the financial state of an enterprise and bring enterprises out of their unsatisfactory condition, if they are in it, by managing and subsequently ensuring their proper financial and economic position.

Formulation of the problem. First of all, the management of the enterprise needs to know the state of the object of management. To do this it is necessary to solve the problem of diagnosing the financial state of the company and to develop actions to ensure its further effective functioning and development.

Diagnosing is the process of determining and studying indicators, which characterize the state of an object. It consists in certain research methods, analysis of the obtained results and their generalization in the form of a conclusion (diagnosis) to determine possible deviations and prevent disturbances in the normal functioning of an object.

The task of diagnosing the financial state of an enterprise is characterized by the difficulty of obtaining information, a large volume of analyzed data, and multicriteria, because a large number of indicators are calculated and investigated.

Existing models and methods of diagnostic of financial state do not take into account the parameters that are quite important in modern conditions, since they do not bring them into consideration; therefore, the financial situation can be determined insufficiently accurately. Some mathematical models take into account a series of key parameters, but do not have the optimal criteria, which are necessary for determining the financial state. Also, uncertain or unclear information may be contained in the initial data and knowledge about the controlled object and that information cannot be processed by traditional quantitative methods [1].

Therefore, in the current economic conditions, the issues of expanding and improving the models for diagnosing financial conditions are relevant.

The problem is in the need to obtain a more accurate solution for the problem of diagnosing the financial state of the enterprise with the parameters that characterize the financial situation best of all.

Thus, the main objective of the research was to solve the problem of diagnosing the financial state of an IT company, using a model that implements a certain approach in order to obtain a qualitative conclusion about the state of a company. The solution way, based on the obtained model, can be automated in the future, which is necessary for the quick and accurate determination of the financial condition of a company in order to improve the efficiency of the financial department and the company as a whole.

The subject of the research is the process of determining the financial state of the enterprise, and the object of the research is some IT-company.

The task and purpose of the research is to analyze the company's financial indicators and determine the financial condition with their help on the basis of the chosen diagnostic method.

The financial state in this case can be evaluated as good, normal or bad.

This article is aimed at implementing the practical aspects of diagnosis of the financial condition of the company. The approach to the diagnosis of the financial state of the company, realized in the construction of diagnosis model, differs from the well-known models of the mathematical apparatus, which allows to carry out diagnostic of the financial state of the company.

It is planned to build a model of diagnosing the financial state of the company such a way that it allows to take into account the optimal number of basic indicators that have a significant impact on the determination of the financial condition of the company with the greatest accuracy.

Thus, the need for accurate diagnosis of the financial condition of the enterprise is due to economic reasons and the reason for the need to make correct and effective management decisions. Solving this problem allows us to accurately assess the current financial position and activity of the enterprise.

Solution Method. The financial state of the company (which is an IT-company) depends on the results of its industrial, commercial and financial activities. It is determined on the basis of a series of indicators that most objectively reflect the trends of change in financial state, as a rule, it consists of four groups: liquidity indicators, financial stability indicators, profitability indicators (profitability), business activity indicators [2].

Analysis of Ukrainian and foreign publications and literary sources showed that the task of diagnosing the financial conditions of an IT-company can be solved using various mathematical approaches, such as: the classical coefficient method with calculating rating score, neural network technology, fuzzy logic apparatus and others [3-6]. 
For illustrate, the authors propose for the solving task of diagnosing financial state of company method based on the using of a fuzzy logic apparatus, namely, production models with the Mamdani fuzzy inference algorithm.

Complex dynamic economic systems (which are enterprises) may be characterized by incomplete information, instability, evolutionary changes, etc. This information is usually characterized by inaccuracy; it comes not in the form of quantitative, but in the form of linguistic variables [7].

In assessing the activity of the enterprise often have to deal with non-numeric data (qualitative characteristics). Many financial indicators do not have a precise rationing and are highly dependent on the scope of the enterprise. In such cases, often resorting to expert estimates. The classical model for assessing the financial condition cannot work with such data, so we can use fuzzy sets in this case.

The methods of fuzzy logic can significantly simplify the description of the model of objects of control and diagnosis, and are easier for hardware implementation.

Fuzzy production models are the most common type of fuzzy models used to describe, analyze and model complex systems and processes that are badly formalized [8].

The fuzzy production system is understood as the agreement of the sets of individual fuzzy production rules of the form "if A, then B", where A and B are the precondition and the conclusion of this rule in the form of fuzzy statements, designed to determine the truth level of the conclusions of fuzzy production rules, based on preconditions with a certain degree of truth of the relevant rules [8].

A fuzzy logical conclusion for a model that reflects the functioning of a company is called approximation of dependence $Y=f\left(x_{1}, x_{2}, \ldots, x_{10}\right)$ using a fuzzy knowledge base and fuzzy operations.

As input linguistic variables using variables, defined on the basis of selected primary financial indicators of the company (obtained from the financial accounting of the company). They are combined into two large groups [9].

The first is a group of quantitative indicators of financial condition

$$
X_{0}=f\left(X_{1}, X_{2}, X_{3}, X_{4}\right),
$$

where $X_{1}$ - group of liquidity ratios, which including $x_{1}$ - current liquidity ratio, $x_{2}$ - absolute liquidity ratio;

$X_{2}$ - group of indicators of financial stability, which including, $x_{3}-$ availability of current assets ratio, $x_{4}-$ debt to equity ratio;

$X_{3}$ - group of profitability indicators, which including $x_{5}-$ indicator of profitability of assets, $x_{6}-$ indicator of profitability of equity;

$X_{4}$ - group of indicators of business activity, which including $x_{7}$ - asset turnover ratio, $x_{8}$ - equity turnover ratio.

Second group $X_{5}$ is quality parameters, which including $x_{9}$ - professional abilities of managers (point), $x_{10}$ - the level of wages and social protection of employees (point) [9].
In order to be able to evaluate and process indicators $x_{i}(i=\overline{1,10})$ that can characterize a company in terms of financial condition, we define a single scale of three quality terms: $\mathrm{L}-$ a low level indicator $x_{i}, \mathrm{M}-\mathrm{a}$ middle level indicator $x_{i}, \mathrm{H}-$ a high level indicator $x_{i}$ [9].

$Y$ will be used as the output linguistic variable. It is the financial state of the company.

The obtained output parameter $Y$ allows us to characterize the financial state of the company as: $\mathrm{G}$ good, $\mathrm{N}$ - normal, B - bad.

Solving the assigned problem also requires solving two subtasks, namely, the problem of parametric and structural identification, i.e. the possible range of variation of the selected parameters $x_{i}$ and the output variable $Y$ must be determined and the type of membership functions of fuzzy terms should be set for the input parameters which are used and for the output parameter too.

The membership function reflects elements from the set $x$ on the set of numbers in the interval $[0,1]$, which indicate the degree of belonging of each element to different qualitative terms [9].

Input indicators may correspond or do not match to recommend or standard values, which are presented in the form of some established intervals. Therefore, the trapezoidal membership function will be used to solve the problem, because it allows us to specify the basis of a fuzzy set as an interval and is simple to set [10].

The levels of all terms of each of the indicators $x_{i}(i=\overline{1,10})$, of a particular enterprise are set in accordance with standard values for classical criteria. If standards for the indicator do not exist, then the levels of the terms are divided on the basis of expert judgments or by comparing the values of the desired indicator for similar enterprises in different periods of time.

We reflect the ranges of change of parameters $x_{i}$, to a single universal set $x$ in order for constructing the membership functions of three fuzzy terms of the input variable $\{\mathrm{L}, \mathrm{M}, \mathrm{H}\}[11]$.

Three fuzzy subsets are set whose membership functions are shown in Figure 1.

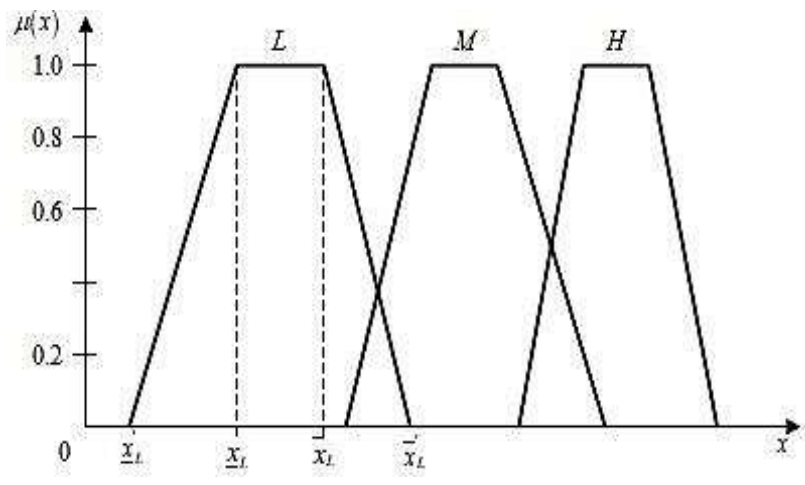

Figure 1 - Fuzzy variable $x$ with a trapezoidal membership function

As an example, we can take the analytical form of writing a trapezoidal membership function of one fuzzy term L of the input variable $x$, shown in Figure 1: 


$$
\mu^{\mathrm{L}}(x)=\left\{\begin{array}{cc}
0, & x<\underline{x}_{\mathrm{L}}^{\prime}, \\
\bar{x}-\underline{x}_{\mathrm{L}}^{\prime}, & \underline{x}_{\mathrm{L}}^{\prime} \leq x \leq \underline{x}_{\mathrm{L}}, \\
\underline{x}_{\mathrm{L}}-\underline{x}_{\mathrm{L}}^{\prime} & \underline{x}_{\mathrm{L}} \leq x \leq \bar{x}_{\mathrm{L}}, \\
\bar{x}_{\mathrm{L}}^{\prime}-\bar{x} & \bar{x}_{\mathrm{L}} \leq x \leq \bar{x}_{\mathrm{L}}^{\prime}, \\
\bar{x}_{\mathrm{L}}^{\prime}-\bar{x}_{\mathrm{L}} & x>\bar{x}_{\mathrm{L}}^{\prime} . \\
0, &
\end{array}\right.
$$

Membership functions of other fuzzy terms of the input variables $x_{i}$ and terms of the output variable $Y$ are built by a similar way.

A system based on fuzzy knowledge should contain a mechanism for fuzzy inference, such as to be possible to judge about the financial state of an enterprise. Therefore, the necessary stage of analysis is the creating of a system of rules [11].

A simple way to build a rule base is a full enumeration method, which will be used to solve the assigned problem.

Rules are given for each level of the system. An example of a decision rule would take the next expression: IF quantitative indicators of FSE are high AND qualitative parameters of FSE are middle OR quantitative indicators of FSE are high AND qualitative parameters of FSE are high, THEN the company's financial state is good.

The mathematical form of writing of a given decision rule using the membership functions is represented as:

$$
\mu^{Y}=\mu^{\mathrm{H}}\left(X_{0}\right) \cdot \mu^{\mathrm{M}}\left(X_{5}\right) \vee \mu^{\mathrm{H}}\left(X_{0}\right) \cdot \mu^{\mathrm{H}}\left(X_{5}\right),
$$

where $\mu^{Y}\left(X_{0}, X_{5}\right)$ - membership function of input variables vector $\left(X_{0}, X_{5}\right)$ to the output variable $Y$;

$$
\mu^{a_{i}}\left(X_{i}\right) \text { - parameter membership function } X \text { to fuzzy }
$$
term $a_{i}$.

Both criteria $X_{0}$ and $X_{5}$, which represent the complex values of the specified groups of indicators, are presented in the form of mathematical dependencies on input variables [3].

The mathematical form of writing of the decision rule for determining the level $\mathrm{H}$ of the quantitative assessment of the FSE $X_{0}$ will take the form:

$$
\begin{aligned}
& \mu^{\mathrm{H}}\left(X_{1}, \ldots, X_{4}\right)=\mu^{\mathrm{H}}\left(X_{1}\right) \cdot \mu^{\mathrm{H}}\left(X_{2}\right) \cdot \mu^{\mathrm{M}}\left(X_{3}\right) \times \\
& \quad \times \mu^{\mathrm{H}}\left(X_{4}\right) \vee \mu^{\mathrm{H}}\left(X_{1}\right) \cdot \mu^{\mathrm{M}}\left(X_{2}\right) \cdot \mu^{\mathrm{H}}\left(X_{3}\right) \times \\
& \quad \times \mu^{\mathrm{H}}\left(X_{4}\right) \vee \mu^{\mathrm{H}}\left(X_{1}\right) \cdot \mu^{\mathrm{H}}\left(X_{2}\right) \cdot \mu^{\mathrm{H}}\left(X_{3}\right) \times \\
& \quad \times \mu^{\mathrm{M}}\left(X_{4}\right) .
\end{aligned}
$$

Next, we need to represent a relation for calculation of each of the generalized indicators of groups of influence factors $X_{1}, \ldots, X_{4}$.

On the example of a group of factors affecting the liquidity of an enterprise $X_{1}$, we can present the rule for determining the generalized indicator of liquidity at level $\mathrm{H}$.

This rule on natural language will be next: IF current liquidity ratio is high AND absolute liquidity ratio is high OR current liquidity ratio is middle AND absolute liquidity ratio is high, THEN the generalized liquidity ratio is high.
Next fuzzy logic equation will correspond to previous linguistic statement:

$$
\mu^{\mathrm{H}}\left(x_{1}, x_{2}\right)=\mu^{\mathrm{H}}\left(x_{1}\right) \cdot \mu^{\mathrm{H}}\left(x_{2}\right) \vee \mu^{\mathrm{M}}\left(x_{1}\right) \cdot \mu^{\mathrm{H}}\left(x_{2}\right) .
$$

The entire knowledge base is formed using the available data in this way, and a system of fuzzy logic equations will derive from it.

Algorithm for solving the problem. Fuzzy inference is the obtaining of a conclusion in the form of a fuzzy set corresponding to the current values of the inputs, using a fuzzy knowledge base and fuzzy operations [12]. The final result of the fuzzy inference is the precise value of the variable $Y$, obtained from the initially defined precise values $x_{i}(i=\overline{1,10})$.

It is proposed to use one of the most common logical inference algorithms in fuzzy systems - the Mamdani algorithm for solving the problem.

The Mamdani fuzzy inference algorithm is implemented by the following steps [12].

At the first step, the predicate rule base is formed in the subject area, for example, using the full enumeration method; next action is checking the input variables: if the variables are precise sets, then go to the next step, which is called the fuzziness introduction stage - fuzzification [12].

In the second step, the fuzzification procedure is performed: each value of a separate input variable is associated with the value of the membership function of the corresponding term of the input linguistic variable [12]

$$
\mu_{1}(x), \mu_{2}(x), \ldots, \mu_{n}(x),
$$

where $\mu_{1}(x), \ldots, \mu_{n}(x)$ - membership functions for variable $x$;

The third step is the aggregation of prerequisites in fuzzy production rules. Paired fuzzy logic operations are used to find the degree of truth of the conditions of each of the rules of fuzzy products [12]:

$$
\begin{gathered}
\alpha_{1}=\min \left\{\mu_{A_{11}}\left(x_{1}^{\prime}\right), \mu_{A_{12}}\left(x_{2}^{\prime}\right), \ldots, \mu_{A_{1 n}}\left(x_{n}^{\prime}\right)\right\}, \\
\alpha_{2}=\min \left\{\mu_{A_{21}}\left(x_{1}^{\prime}\right), \mu_{A_{22}}\left(x_{2}^{\prime}\right), \ldots, \mu_{A_{2 n}}\left(x_{n}^{\prime}\right)\right\}, \\
\ldots \ldots \ldots \ldots . \\
\alpha_{m}=\min \left\{\mu_{A_{m 1}}\left(x_{1}^{\prime}\right), \mu_{A_{m 2}}\left(x_{2}^{\prime}\right), \ldots, \mu_{A_{m n}}\left(x_{n}^{\prime}\right)\right\},
\end{gathered}
$$

where $m$ - number of variables;

$n$-number of rules in the base.

The fourth step is the activation procedure - finding the truncated membership function for the output variable, which is made according to the formulas [12]:

$$
\begin{aligned}
\mu_{B_{1}^{\prime}}= & \min \left\{\alpha_{1}, \mu_{B_{1}}(Y)\right\}, \\
\mu_{B_{2}^{\prime}}= & \min \left\{\alpha_{2}, \mu_{B_{2}}(Y)\right\}, \\
& \cdots \cdots \ldots \ldots . . . \\
\mu_{B_{m}^{\prime}}= & \min \left\{\alpha_{m}, \mu_{B_{m}}(Y)\right\} .
\end{aligned}
$$

The fifth step is the procedure of accumulating or combining the found truncated functions in order to obtain the final fuzzy set for the output variable and the resulting 
membership function, which is performed according to the formula [12]:

$$
\mu_{B^{\prime}}(Y)=\max \left\{\mu_{B_{1}^{\prime}}(Y), \mu_{B_{2}^{\prime}}(Y), \ldots, \mu_{B_{m}^{\prime}}(Y)\right\} .
$$

The sixth and final step is defuzzification, or bringing to precision. Most often, the Mamdani model uses defuzzification by the centroid method, when a precise value of the output variable is defined as the center of gravity for the curve:

$$
Y^{\prime}=\frac{\sum_{i=1}^{n} Y_{i} \mu_{B^{\prime}}\left(Y_{i}\right)}{\sum_{i=1}^{n} \mu_{B^{\prime}}\left(Y_{i}\right)},
$$

where $n$-the number of single-point fuzzy sets, each of which characterizes a single value of the considered output linguistic variable;

$Y^{\prime}$ - financial condition of the company [12].

Thus, having a rule base and using the algorithm above, we can get the result of a fuzzy inference, represented by the output parameter of a given model, namely, the financial condition of the company.

Numerical research. The process of solving the problem of diagnosing the financial state of IT-company can be illustrated using the MATLAB package.

Table 1 shows the values of the financial indicators of the studied company, obtained on the basis of the reporting forms of the company's financial activities (balance sheet) over the past few years.

Table 2 shows the trapezoidal numbers characterizing the corresponding membership functions for each indicator $x_{i}$.

Membership functions were built for the linguistic variable "Indicator" with the help of the MATLAB environment. An example of building the membership functions of the linguistic variable "Indicator" for the parameter $x_{1}$ is shown in Figure 2.

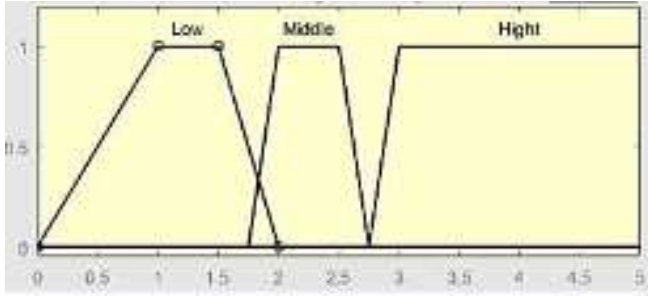

Figure 2-Graphs of the membership functions of the linguistic variable "Indicator" for the parameter $x_{1}$

The membership functions of the linguistic variable "Indicator" is constructed for the remaining parameters $x_{i}$ by the similar way.

Then, a rule base is created for each level of the system using data and MATLAB tools: first for determining the generalized indicators $X_{1}, \ldots, X_{4}, X_{5}$, then for obtaining the complex criterion $X_{0}$ and finally for determining the output parameter $Y$ - the financial state of the company. As a result, the rule base will contain 135 rules.

Examples of the first two and the last two rules, which were formed in MATLAB, are given below.

Rules formed in MATLAB:

1. If ( $\mathrm{x} 1$ is Low) and ( $\mathrm{x} 2$ is Low) then ( $\mathrm{X} 1$ is Low);

2. If ( $\mathrm{x} 1$ is Low) and ( $\mathrm{x} 2$ is Middle) then ( $\mathrm{X} 1$ is Middle);

134. If ( $\mathrm{X} 0$ is High) and ( $\mathrm{X} 5$ is Low) then ( $\mathrm{Y}$ is Normal);

135. If ( $\mathrm{X} 0$ is Low) and ( $\mathrm{X} 5$ is High) then ( $\mathrm{Y}$ is $\mathrm{Bad}$ ).

We can illustrate the obtaining of a generalized liquidity index $X_{1}$ using the Mamdani algorithm, implemented in MATLAB (Fig. 3).

Table 1 - Values of the selected financial indicators of the company

\begin{tabular}{|c|c|c|c|c|c|c|c|c|c|c|}
\hline Indicator / Year & $x_{1}$ & $x_{2}$ & $x_{3}$ & $x_{4}$ & $x_{5}$ & $x_{6}$ & $x_{7}$ & $x_{8}$ & $x_{9}$ & $x_{10}$ \\
\hline 2018 & 12.6 & 8.82 & 0.4 & 0.31 & 0.26 & 0.13 & 0.7 & 3.8 & 8.5 & 9 \\
\hline 2017 & 3.92 & 0.89 & 0.29 & 0.58 & 0.48 & 0.57 & 3.23 & 4.95 & 7.5 & 7.9 \\
\hline 2016 & 2.6 & 0.52 & 0.33 & 0.48 & 0.17 & 0.46 & 2.73 & 4.38 & 5.5 & 7.6 \\
\hline 2015 & 1.7 & 0.03 & 0.53 & 0.67 & 0.19 & 0.15 & 1.67 & 4.25 & 4.9 & 3.6 \\
\hline
\end{tabular}

\begin{tabular}{|c|c|c|c|}
\hline Value / Indicator & Low & Middle & High \\
\hline$x_{1}$ & {$\left[\begin{array}{lllll}0 & 1 & 1.5 & 2\end{array}\right]$} & {$\left[\begin{array}{lllll}1.75 & 2 & 2.5 & 2.75\end{array}\right]$} & {$\left[\begin{array}{lllll}2.75 & 3 & 4 & \infty\end{array}\right]$} \\
\hline$x_{2}$ & {$\left[\begin{array}{lllll}0 & 0.1 & 0.15 & 0.2\end{array}\right]$} & {$\left[\begin{array}{lllll}0.2 & 0.25 & 0.5 & 0.75\end{array}\right]$} & {$\left[\begin{array}{lll}0.7 & 0.9 \infty \infty\end{array}\right]$} \\
\hline$x_{3}$ & {$\left[\begin{array}{lllll}0 & 0.1 & 0.25 & 0.3\end{array}\right]$} & {$\left[\begin{array}{lllll}0.25 & 0.3 & 0.5 & 0.6\end{array}\right]$} & {$\left[\begin{array}{lllll}0.5 & 0.75 & 1 & 1\end{array}\right]$} \\
\hline$x_{4}$ & {$\left[\begin{array}{lllll}0 & 0.2 & 0.4 & 0.5\end{array}\right]$} & {$\left[\begin{array}{lllll}0.45 & 0.5 & 0.6 & 0.7\end{array}\right]$} & {$\left[\begin{array}{lllll}0.65 & 0.75 & 1 & 1\end{array}\right]$} \\
\hline$x_{5}$ & {$\left[\begin{array}{lllll}0 & 0.1 & 0.15 & 0.2\end{array}\right]$} & {$\left[\begin{array}{llll}0.2 & 0.3 & 0.4 & 0.5\end{array}\right]$} & {$\left[\begin{array}{lllll}0.4 & 0.5 & 1 & \infty\end{array}\right]$} \\
\hline$x_{6}$ & {$\left[\begin{array}{lllll}0 & 0.1 & 0.15 & 0.25\end{array}\right]$} & {$\left[\begin{array}{llll}0.2 & 0.3 & 0.4 & 0.5\end{array}\right]$} & {$\left[\begin{array}{llll}0.45 & 0.5 & 1 & \infty\end{array}\right]$} \\
\hline$x_{7}$ & {$\left[\begin{array}{llll}0 & 0.5 & 1.5 & 2\end{array}\right]$} & {$\left[\begin{array}{llllll}2 & 3.5 & 5 & 7.5\end{array}\right]$} & {$\left[\begin{array}{llll}7 & 8 & 10 & \infty\end{array}\right]$} \\
\hline$x_{8}$ & {$\left[\begin{array}{lllll}0 & 2 & 3.5 & 4.5\end{array}\right]$} & {$\left[\begin{array}{llll}4 & 4.6 & 7 & 8.5\end{array}\right]$} & {$\left[\begin{array}{lllll}8.5 & 9 & 10 & \infty\end{array}\right]$} \\
\hline$x_{9}$ & {$\left[\begin{array}{llll}0 & 1 & 3 & 5\end{array}\right]$} & {$\left[\begin{array}{llll}4.5 & 5 & 7 & 8.5\end{array}\right]$} & {$\left[\begin{array}{llll}8 & 9 & 10 & 10\end{array}\right]$} \\
\hline$x_{10}$ & {$\left[\begin{array}{llll}0 & 1 & 3 & 4\end{array}\right]$} & {$\left[\begin{array}{llll}3.7 .75 & 5 & 7 & 8\end{array}\right]$} & {$\left[\begin{array}{lllll}7.5 & 8 & 10 & 10\end{array}\right]$} \\
\hline$X_{i}, i=\overline{0,5}$ & {$\left[\begin{array}{llll}0 & 1 & 2 & 2.5\end{array}\right]$} & {$\left[\begin{array}{lllll}2.5 & 3 & 3.5 & 4\end{array}\right]$} & {$\left[\begin{array}{lllll}4 & 4.25 & 4.75 & 5\end{array}\right]$} \\
\hline
\end{tabular}

Table 2 - T-numbers for the values of the linguistic variable "Indicator" 


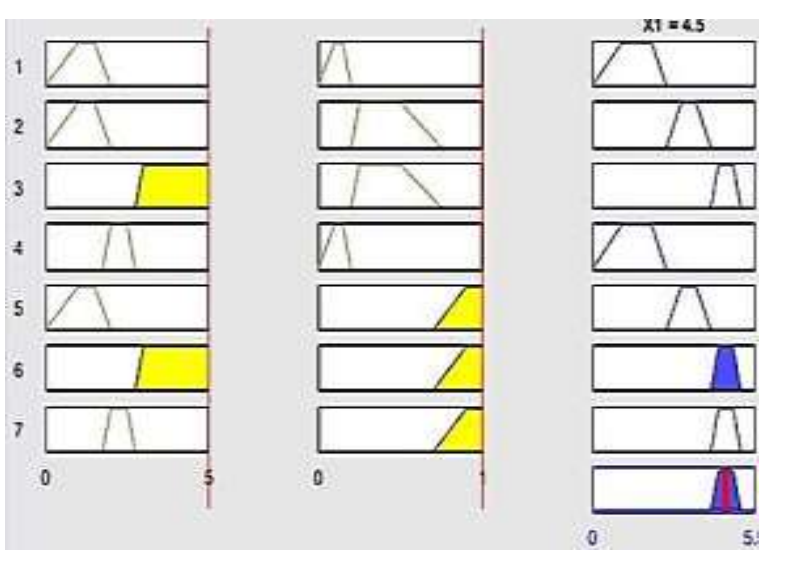

Figure 3 - Obtaining a generalized liquidity ratio $X_{1}$ (for 2018)

Figure 3 shows the result of accumulation, i.e. obtaining the final fuzzy set for the output variable $X_{1}$ and also shows the result of defuzzification using the centroid method.

Thus, it is clear that the generalized liquidity ratio is high. We obtain the remaining generalized indicators $X_{1}, \ldots, X_{4}, X_{5}$ and $X_{0}$ by the similar way (Table 3 ).

Table 3 - Generalized indicators of the company and $X_{0}$

\begin{tabular}{|c|c|c|c|}
\hline Year & $\begin{array}{c}\text { Generalized } \\
\text { indicator }\end{array}$ & Value & Description \\
\hline \multirow{4}{*}{2018} & $X_{1}$ & 4.5 & High \\
\cline { 2 - 4 } & $X_{2}$ & 1.36 & Low \\
\cline { 2 - 4 } & $X_{3}$ & 3.25 & Middle \\
\cline { 2 - 4 } & $X_{4}$ & 1.33 & Low \\
\cline { 2 - 4 } & $X_{5}$ & 4.5 & High \\
\hline \multirow{4}{*}{2017} & $X_{0}$ & 3.25 & Middle \\
\cline { 2 - 4 } & $X_{1}$ & 4.5 & High \\
\cline { 2 - 4 } & $X_{2}$ & 2.56 & Middle \\
\cline { 2 - 4 } & $X_{3}$ & 4.12 & High \\
\hline \multirow{4}{*}{2016} & $X_{4}$ & 3.25 & Middle \\
\cline { 2 - 4 } & $X_{5}$ & 4.24 & High \\
\cline { 2 - 4 } & $X_{0}$ & 4.5 & High \\
\cline { 2 - 4 } & $X_{1}$ & 2.75 & Middle \\
\cline { 2 - 4 } & $X_{2}$ & 2.47 & Middle \\
\cline { 2 - 4 } & $X_{3}$ & 1.77 & Low \\
\hline \multirow{4}{*}{2015} & $X_{4}$ & 2.61 & Middle \\
\cline { 2 - 4 } & $X_{5}$ & 3.58 & Middle \\
\cline { 2 - 4 } & $X_{0}$ & 3.25 & Middle \\
\cline { 2 - 4 } & $X_{1}$ & 1.29 & Low \\
\cline { 2 - 4 } & $X_{2}$ & 3.54 & Middle \\
\hline$X_{3}$ & 1.27 & Low \\
\hline$X_{4}$ & 1.3 & Low \\
\hline$X_{5}$ & 2.87 & Middle \\
\hline & $X_{0}$ & 1.35 & Low \\
\hline
\end{tabular}

Next, we need to build membership functions for the linguistic variable "The financial condition of the company." The graphs of the membership functions for the linguistic variable "The financial condition of the company" are shown in Figure 4.

We can get the output parameter $Y$ - the financial condition of the company using the Mamdani algorithm and having data of input parameters (quantitative - a complex indicator $X_{0}$ and qualitative - a generalized indicator $X_{5}$ ) (Fig. 5).

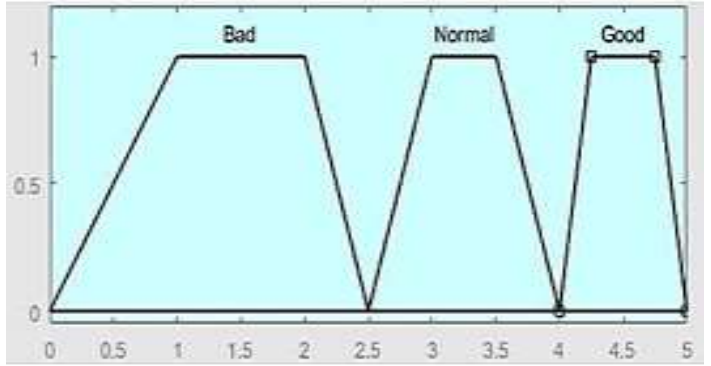

Figure 4 - Graphs of the membership functions of the linguistic variable "The financial condition of the company"
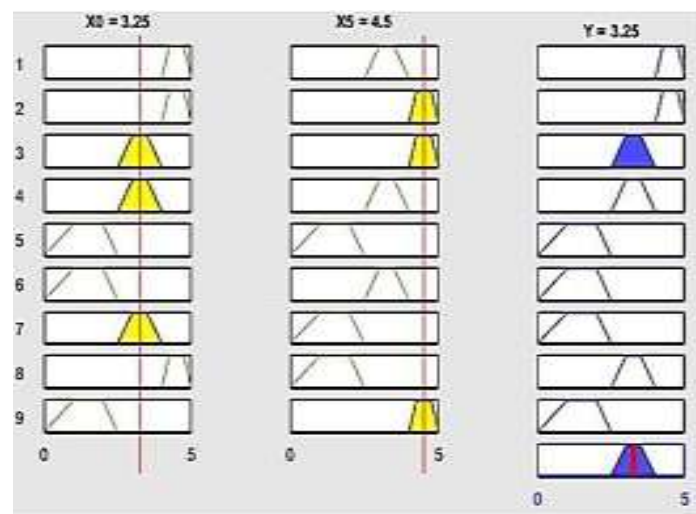

Figure 5 - Determination of the financial state $Y$ (for 2018)

Figure 5 shows the result of the accumulation process - obtaining the final fuzzy set for the output variable $Y$, and also shows the result of defuzzification by the centroid method.

After completing all the above steps, we got the conclusion that the company's financial state is normal.

Table 4 shows the results of the research, which reflect the state of the company over the past few years.

Table 4 - The financial state of the company, obtained as a the result of research

\begin{tabular}{|c|c|c|}
\hline Year & Value & State \\
\hline 2018 & 3.25 & Normal \\
\hline 2017 & 4.5 & Good \\
\hline 2016 & 3.25 & Normal \\
\hline 2015 & 1.33 & Bad \\
\hline
\end{tabular}

Investigate the change of membership functions depending on changes in the values of input parameters.

To do this, we change the parameters $x_{1}, x_{2}$ (leaving the remaining values of the financial indicators for 2018) affecting the generalized liquidity ratio, investigate the changes in the value of the generalized indicator $X_{1}$, the complex indicator $X_{0}$ and the financial condition $Y$. The results are presented in table 5 .

Similarly, we change the parameters $x_{5}, x_{6}$, affecting the generalized profitability index, investigate the changes in the value of the generalized indicator $X_{3}$, the complex indicator $X_{0}$ and the financial condition $Y$. The results are presented in table 6 .

Next, we change the parameters $x_{9}, x_{10}$, investigate the changes in the value of the generalized quality indicator $X_{5}$, and the financial state $Y$. The results are presented in table 7 . 
Table 5 - Changes in values $X_{1}, X_{0}, Y$

\begin{tabular}{|c|c|c|c|c|c|c|c|c|}
\hline & \multicolumn{2}{|c|}{ Indicator } & $\begin{array}{c}\text { Generalized } \\
\text { indicator } X_{1}\end{array}$ & Description & $\begin{array}{c}\text { Complex } \\
\text { indicator } X_{0}\end{array}$ & Description & $\begin{array}{c}\text { Financial } \\
\text { state } Y\end{array}$ & Description \\
\cline { 2 - 8 } & $x_{1}$ & $x_{2}$ & High & 3.25 & Middle & 3.25 & Normal \\
\hline 2018 & 12.6 & 8.82 & 4.5 & High & 3.25 & Middle & 3.25 & Normal \\
\hline 2017 & 3.92 & 0.89 & 4.5 & Middle & 1.31 & Low & 1.36 & Bad \\
\hline 2016 & 2.6 & 0.52 & 2.75 & Low & 1.36 & Low & 1.36 & Bad \\
\hline
\end{tabular}

Table 6 - Changes in values $X_{3}, X_{0}, Y$

\begin{tabular}{|c|c|c|c|c|c|c|c|c|}
\hline & \multicolumn{2}{|c|}{ Indicator } & \multirow{2}{*}{$\begin{array}{c}\text { Generalized } \\
\text { indicator } X_{3}\end{array}$} & Description & $\begin{array}{c}\text { Complex } \\
\text { indicator } X_{0}\end{array}$ & Description & $\begin{array}{c}\text { Financial } \\
\text { state } Y\end{array}$ & Description \\
\cline { 2 - 7 } & $x_{5}$ & $x_{6}$ & Middle & 3.25 & Middle & 3.25 & Normal \\
\hline 2018 & 0.26 & 0.13 & 3.25 & High & 3.25 & Middle & 3.25 & Normal \\
\hline 2017 & 0.48 & 0.57 & 4.12 & Low & 1.36 & Low & 1.36 & $\mathrm{Bad}$ \\
\hline 2016 & 0.17 & 0.46 & 1.77 & Low & 1.36 & Low & 1.36 & $\mathrm{Bad}$ \\
\hline 2015 & 0.19 & 0.15 & 1.27 & &
\end{tabular}

Table 7 - Changes in values $X_{5}, Y$

\begin{tabular}{|c|c|c|c|c|c|c|}
\hline & \multicolumn{2}{|c|}{ Indicator } & \multirow{2}{*}{ Generalized indicator $X_{5}$} & Description & Financial state $Y$ & Description \\
\cline { 2 - 3 } & $x_{9}$ & $x_{10}$ & & High & 3.25 & Normal \\
\hline 2018 & 8.5 & 9 & 4.5 & High & 3.25 & Normal \\
\hline 2017 & 7.5 & 7.9 & 4.24 & Low & 3.25 & Normal \\
\hline 2016 & 5.5 & 7.6 & 3.58 & Low & 3.25 & Normal \\
\hline 2015 & 4.9 & 3.6 & 2.87 & & & \\
\hline
\end{tabular}

Conclusions. After analyzing the problem and the relevance of the research problem, the statement of the problem was formulated. The existing approaches for solving the problem of diagnosing financial states were considered during the research. As a result of the review, and to illustrate the example, the authors suggested using an approach based on the use of a fuzzy logic apparatus, namely, production models with the Mamdani fuzzy inference algorithm.

To determine the financial state were selected 10 input parameters. The criteria by which the state is assessed were quantitative and qualitative indicators of company's activity. The presented mathematical model allows to take into consideration both quantitative and qualitative indicators and also allow to analyze financial groups of indicators (liquidity, financial stability, profitability and business activity), and assess the level of managerial skills.

The implementation of research results can help speed up the diagnosis of the financial state of the enterprise and make a right management decision based on the results of diagnosis in time.

\section{References}

1. Методы робастного, нейро-нечёткого и адаптивного управления: Учебник / ред. Н.Д. Егупов. Изд. 2-е. Москва: Изд-во МГТУ им Н. Э. Баумана, 2002. 744 с.

2. Русак Н. А., Русак В. А. Диагностика финансового состояния предприятия. Труд и сочиальные отношения. Москва: АТИСО. 2012. № 9. С. 120-126.
3. Стоянов Е. А., Стоянова Е. С. Экспертная диагностика и аудит финансово-хозяйственного положения предприятия. Москва: Перспектива, 1993. 89 с.

4. Ковалев А. П. Диагностика банкротства. Москва: АО "Финстатинформ", 1995.96 с.

5. Плышевский Б. П. Финансовое положение: новые тенденции. Финансы. Москва: Изд-во "Книжная редакция финансы". 2003. № 2. С. 18-20.

6. Ротштейн А.П. Интеллектуальные технологии идентификации: нечеткие множества, генетические алгоритмы, нейронные сети. Винница: Універсум-Вінниця, 1999. $320 \mathrm{c}$.

7. Орлов А. И. Нечисловая статистика. Москва: МЗ-Пресс, 2004. $513 \mathrm{c}$.

8. Самарский А. А., Михайлов А. П. Математическое моделирование. Идеи. Методы. Примеры. 2-е изд. Москва: Физматлит, 2001. 320 с.

9. Матвийчук А. В., Сметанюк О. А. Диагностирование финансового состояния предприятия с применением инструментария нечеткой логики. Фінанси Украӥни. Київ: ДННУ "Академія фінансового управління". 2007. № 12. С. 115-128.

10 Штовба С. Д. Введение в теорию нечетких множеств и нечеткую логику. URL: http://matlab.exponenta.ru/fuzzylogic/book1/index.php (дата обращения: 25.02.2019).

11. Матвийчук А. В. Аналіз та прогнозування розвитку фінансовоекономічних систем із використанням теорії нечіткої логіки. Київ: Центр навчальної літератури, 2005. 183 с.

12. Борисов В. В., Круглов В. В., Федулов А. С. Нечеткие модели и сети. 2-е изд. Москва: Горячая линия-Телеком, 2012. 284 с.

\section{References (transliterated)}

1. N. D. Egupov, ed. Metody robastnogo, neyro-nechetkogo $i$ adaptivnogo upravleniya. Uchebnik [Methods of robust, neuro-fuzzy 
and adaptive control: Tutorial]. 2-e izd. Moscow, MGTU im N. E Baumana Publ., 2002. 744 p.

2. Rusak N. A., Rusak V. A. Diagnostika finansovogo sostoyaniya predpriyatiya [Diagnostics of the financial condition of the company]. Trud $i$ sotsial'nye otnosheniya [Labor and social relations]. Moscow, ATISO Publ., 2012, no 9, pp. 120-126.

3. Stoyanov E. A., Stoyanova E. S. Ekspertnaya diagnostika $i$ audit finansovo-khozyaystvennogo polozheniya predpriyativa [Expert diagnostics and audit of the financial and economic situation of the enterprise]. Moscow, Perspektiva Publ., 1993. 89 p.

4. Kovalev A. P. Diagnostika bankrotstva [Диагностика банкротства] Moscow, AO "Finstatinform" Publ., 1995. 96 p.

5. Plyshevskiy B. P. Finansovoe polozhenie: novye tendentsii [Financial situation: new trends]. Finansy [Finances]. Moscow, "Knizhnaya redaktsiya finansy" Publ., 2003, no 2, pp. 18-20.

6. Rotshteyn A. P. Intellektual'nye tekhnologii identifikatsii: nechetkie mnozhestva, geneticheskie algoritmy, neyronnye seti [Intellectual identification technologies: fuzzy sets, genetic algorithms, neural networks]. Vinnitsa, Universum-Vinnytsya Publ., 1999. 320 p.

7. Orlov A. I. Nechislovaya statistika [Non-numeric statistics]. Moscow, MZ-Press Publ., 2004. 513 p.
8. Samarskiy A. A., Mikhaylov A. P. Matematicheskoe modelirovanie. Idei. Metody. Primery [Math modeling. Ideas. Methods. Examples]. 2-e izd. Moscow, Fizmatlit Publ., 2001. 320 p.

9. Matviychuk A. V., Smetanyuk O. A. Diagnostirovanie finansovogo sostoyaniya predpriyatiya s primeneniem instrumentariya nechetkoy logiki [Diagnosing the financial condition of an enterprise using fuzzy logic tools]. Finansy Ukrayiny [Finance of Ukraine]. Kiev, SAI "Academy of Financial Management" Publ., 2007, no 12, pp. 115128.

10. Shtovba S. D. Vvedenie v teoriyu nechetkikh mnozhestv i nechetkuyu logiku [Introduction to the theory of fuzzy sets and fuzzy logic]. Available at: http://matlab.exponenta.ru/fuzzylogic/book1/index.php (accessed 20.01.2013)

11. Matviychuk A. V. Analiz ta prohnozuvannya rozvytku finansovoekonomichnykh system iz vykorystannyam teoriyi nechitkoyi lohiky [Analysis and forecasting of the development of financial and economic systems using the theory of fuzzy logic]. Kiev, Tsentr navchal'noyi literatury Publ., 2005. 183 p.

12. Borisov V. V., Kruglov V. V., Fedulov A. S. Nechetkie modeli i seti [Fuzzy models and networks]. 2-e izd. Moscow, Goryachaya liniyaTelekom Publ., 2012. 284 p

Received 26.03.2019

\section{Відомості про авторів / Сведения об авторах / About the Authors}

Голоскоков Олександр Свгенович (Голоскоков Александр Евгеньеви, Goloskokov Alexander Evgenievich) - кандидат технічних наук, доцент, Національний технічний університет «Харківський політехнічний інститут», професор кафедри Програмної інженерії та інформаційних технологій управління; м. Харків, Україна; ORCID: https://orcid.org/0000-0003-1824-6255; e-mail: prof.goloskokov@gmail.com

Ткаченко Дарія Вадимівна (Ткаченко Дария Вадимовна, Tkachenko Daria Vadimovna) - Національний технічний університет «Харківський політехнічний інститут», студент; м. Харків, Україна; ORCID: https://orcid.org/0000-0002-5234-1013; e-mail: tka4enko.daha@gmail.com 